\title{
Efficient charge storage in dual-redox electrochemical capacitors through reversible counterion-induced solid complexation
}

\author{
Brian Evanko, ${ }^{\dagger, \#}$ Seung Joon Yoo, ${ }^{*,+, \#}$ Sang-Eun Chun, ${ }^{\perp}$ Xingfeng Wang, Xiulei Ji, , Shannon \\ W. Boettcher, ${ }^{*, \S}$ and Galen D. Stucky $*, \dagger, \dagger$ \\ ${ }^{\dagger}$ Materials Department, University of California, Santa Barbara, California 93106, USA. \\ tDepartment of Chemistry \& Biochemistry, University of California, Santa Barbara, California 93106, USA.

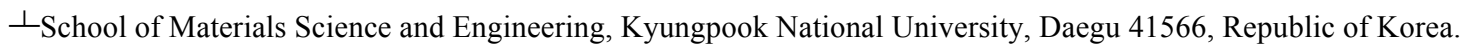 \\ || Department of Chemistry, Oregon State University, Corvallis, Oregon 97331, USA. \\ ${ }^{\S}$ Department of Chemistry and Biochemistry, University of Oregon, Eugene, Oregon 97403, USA.
}

${ }^{\#}$ These authors contributed equally.

*Email: sjyoo@chem.ucsb.edu, swb@uoregon.edu, stucky@chem.ucsb.edu

\section{Experimental information}

Materials. All reagents and starting materials were obtained commercially and used as received without any further purification:

$n$-bromobutane, $n$-bromopentane, $n$-bromohexane, sodium bromide $(\mathrm{NaBr})$, sodium dithionite $\left(\mathrm{Na}_{2} \mathrm{~S}_{2} \mathrm{O}_{4}\right)$, and polytetrafluoroethylene (60 weight $\%$ aqueous dispersion) were purchased from Sigma-Aldrich. Acetonitrile, heptyl viologen, and 4,4'-bipyridine were purchased from TCI America. Methyl viologen and hydrobromic acid $(\mathrm{HBr})$ were purchased from Acros Organics. Sodium bromate $\left(\mathrm{NaBrO}_{3}\right)$ was purchased from J. T. Baker Chemical Co., isopropanol was purchased from VWR, and potassium bromide $(\mathrm{KBr})$ was purchased from EMD Chemicals Inc. Water was from a Milli-Q Simplicity ${ }^{\mathrm{TM}} 185$ system with resistivity $\geq 18.2 \mathrm{M} \Omega \cdot \mathrm{cm}$ (if not specified, all solutions in the following paragraphs refer to aqueous solutions.)

Activated carbon. Activated carbon was prepared by physical $\mathrm{CO}_{2}$ activation of high-purity coal tar pitch-based carbon fibers (Donacarbo S-241, Osaka Gas Co., $13 \mu \mathrm{m}$ OD x $130 \mu \mathrm{m}$ long). ${ }^{1}$ Carbon fibers $(1 \mathrm{~g})$ were heated in a tube furnace at $890{ }^{\circ} \mathrm{C}$ under flowing $\mathrm{CO}_{2}(100 \mathrm{SCCM})$ for $22.5 \mathrm{~h}$. The resulting activated carbon had a $26.8 \%$ yield (73.2 \% burn-off), a Brunauer-Emmett-Teller (BET) specific surface area of $2,470 \mathrm{~m}^{2} \mathrm{~g}^{-1}$, and a methylene-blue-accessible specific surface area of 1,620 $\mathrm{m}^{2} \mathrm{~g}^{-1}$. Additional details, including elemental composition and pore size distribution are reported in the literature. ${ }^{2}$ 
Viologen bromide salts. Symmetric viologens were synthesized by $\mathrm{N}$-alkylation of 4,4'-bipyridine with various alkyl halides under microwave irradiation conditions.

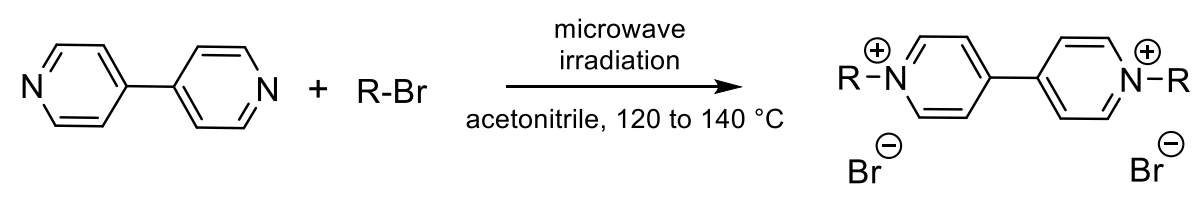

For the synthesis of pentyl viologen (1,1'-dipentyl-4,4'-bipyridinium dibromide), $700 \mathrm{mg}$ of 4,4'-bipyridine ( 1 equiv) was dissolved in $7.5 \mathrm{~mL}$ of acetonitrile, and $5 \mathrm{~mL}$ of excess 1-bromopentane (ca. 10 equiv) was added in a $20 \mathrm{~mL}$ microwave reactor vial. The reaction was carried out in three stages in a Biotage Initiator Classic Microwave Synthesizer as follows: $2 \mathrm{~min}$. at $120^{\circ} \mathrm{C}, 20 \mathrm{~min}$. at $135^{\circ} \mathrm{C}$, and $10 \mathrm{~min}$. at $140{ }^{\circ} \mathrm{C}$, with stirring at $600 \mathrm{rpm}$. Reaction progress was monitored by TLC (10\% water/20\% methanol/70\% acetic acid as an eluent) until the reaction was terminated when the starting 4,4'-bipyridine was consumed and the mono-substituted byproduct disappeared. After the reaction, the reaction mixture was filtered, washed with acetonitrile several times, and dried for 2 days under vacuum at room temperature. Pentyl viologen ( $1.5 \mathrm{~g}$; $3.3 \mathrm{mmol} ; 73 \%$ yield), was obtained as a yellow crystalline solid whose spectral properties matched those reported in the literature. ${ }^{3}$ The same procedure was used for butyl viologen (1,1'-dibutyl-4,4'-bipyridinium dibromide) and hexyl viologen (1,1'-dihexyl-4,4'-bipyridinium dibromide) with slight modifications: For butyl viologen, $700 \mathrm{mg}$ of 4,4'-bipyridine was dissolved in $5 \mathrm{~mL}$ acetonitrile and $5 \mathrm{~mL}$ 1-bromobutane. For hexyl viologen, $700 \mathrm{mg}$ of 4,4'-bipyridine was dissolved in $5 \mathrm{~mL}$ acetonitrile and $7.5 \mathrm{~mL}$ 1-bromohexane. All spectroscopic data were consistent with those reported for these compounds. ${ }^{3}$

Tribromide $\left(\mathrm{Br}_{3}{ }^{-}\right)$solution. Bromine and $\mathrm{Br}_{3}{ }^{-}$were generated using the following chemical reactions: ${ }^{4}$

$$
\begin{gathered}
\mathrm{NaBrO}_{3}+5 \mathrm{Br}^{-}+6 \mathrm{H}^{+} \rightarrow 3 \mathrm{Br}_{2(\mathrm{aq})}+3 \mathrm{H}_{2} \mathrm{O} \\
\mathrm{Br}_{2(\mathrm{aq})}+\mathrm{Br}^{-} \rightleftharpoons \mathrm{Br}_{3}^{-} \quad\left(\mathrm{K}_{\mathrm{eq}}=16.1 \mathrm{M}^{-1}\right)
\end{gathered}
$$

To produce a $10 \mathrm{~mL}$ stock solution of $120 \mathrm{mM} \mathrm{Br}_{3}^{-}, 3 \mathrm{~mL}$ of $2 \mathrm{M} \mathrm{HBr}, 3 \mathrm{~mL}$ of $2 \mathrm{M} \mathrm{KBr}$, and $4 \mathrm{~mL}$ of 0.1 $\mathrm{M} \mathrm{NaBrO}_{3}$ were combined in a glass vial and stirred for 10 minutes. The resulting $\mathrm{Br}_{3}{ }^{-}$solution is dark orange. 


\section{Fabrication of redox-enhanced electrochemical capacitors (redox ECs)}

Carbon electrodes. $0.056 \mathrm{~g}$ of polytetrafluoroethylene (PTFE) binder (60 weight \% aqueous dispersion), $0.033 \mathrm{~g}$ of acetylene black conductive additive (Vulcan ${ }^{\circledR} \mathrm{XC} 72 \mathrm{R}$ ), and $4 \mathrm{~mL}$ isopropanol were combined and mixed in a $10 \mathrm{~mL}$ mixing cup for 2 minutes on a vortex mixer followed by 5 minutes on a FlackTek high shear mixer at $2000 \mathrm{rpm}$. Next, $600 \mathrm{mg}$ of activated carbon was added to the resulting slurry and the mixing steps were repeated. The resulting material was rolled with a PTFE rolling pin and folded over itself 5-10 times until a single freestanding film was formed. This film was dried overnight at $160{ }^{\circ} \mathrm{C}$ in air, ground into a powder through mesh sieve, and then dried again under high vacuum at room temperature. The resulting electrode material contained activated carbon, carbon black conductive additive, and PTFE binder in a 90:5:5 mass ratio, respectively. Freestanding $10 \mathrm{mg}$ electrode pellets were pressed from the powder in a $1 \mathrm{~cm}$ die (MTI Corporation) on a Carver hydraulic press under an applied uniaxial force of 2 tons, applied 3 times. Electrodes were $1 \mathrm{~cm}$ in diameter and $300 \pm 5 \mathrm{um}$ thick, for a total volume of $0.024 \mathrm{~cm}^{3}$, density of $0.42 \mathrm{~g} / \mathrm{cm}^{3}$, and areal mass loading of $12.7 \mathrm{mg} / \mathrm{cm}^{2}$.

Building the cell stack. To build each symmetric cell, two electrodes were placed in a glass cup and immersed in $1.5 \mathrm{~mL}$ of electrolyte. To infiltrate the hydrophobic electrodes with aqueous electrolyte, vacuum and nitrogen (150 psi) were alternately applied for 5 minute intervals, 10 times. The process was carried out twice to ensure the electrolyte was thoroughly infiltrated. Electrodes were removed from the excess electrolyte and assembled into a cell stack by placing them on either side of an electrolyte-wetted, $12 \mathrm{~mm}$ diameter filter paper or polycarbonate separator (Whatman \#1 or Sterlitech PCT069030, respectively).

Cell assembly. Cell bodies were formed by boring out the center of $1 / 2$ " Swagelok PFA Unions. Current collectors were formed by bonding 3-mm-thick type 1 glassy carbon discs (Alfa Aesar) to the ends of 12 mm diameter stainless steel rods (McMaster-Carr) with silver epoxy (CW2400 - Chemtronics), and encapsulating the sides of the disc and rod in electrically insulating and chemically protective epoxy (Stycast 1266 - Emmerson and Cumming). The cell stack was placed between the two glassy-carboncapped current collectors inside the cell body. The assembly was held together by tightening the PFA nuts and ferrules while applying $\sim 50$ psi of pressure on the stack through the current collectors. For the threeelectrode configuration tests, a T-shaped Swagelok PFA union was used with an $\mathrm{Ag} / \mathrm{AgCl}$ reference electrode (Fisher Scientific ${ }^{\mathrm{TM}}$ accumet $^{\mathrm{TM}}$ ) placed with the tip at the edge of the separator with $0.5 \mathrm{~mL}$ of excess electrolyte added to submerge the reference electrode frit. Cell assemblies are shown in Figure S1. 
Electrochemical characterization of redox ECs. All galvanostatic charge/discharge (GCD) cycling tests were performed on a Bio-logic VMP3 potentiostat/galvanostat at a temperature of $25 \pm 1{ }^{\circ} \mathrm{C}$. Glassy carbon surfaces of the current collectors were polished using polishing alumina $(0.05 \mu \mathrm{m})$ and then washed with water and methanol prior to any measurements. The applied current, $I$, for GCD testing was normalized to the dry mass (activated carbon, carbon black, and PTFE binder) of both positive and negative electrodes (denoted as $\mathrm{A} / \mathrm{g}_{\text {dry }}$ ) - e.g., a current of $\pm 20 \mathrm{~mA}$ was applied to cycle a cell with symmetric $10 \mathrm{mg}$ electrodes at a rate of $1 \mathrm{~A} / \mathrm{g}_{\text {dry }}$.

Voltage, $V$, is measured as a function of time, $t$, and charging or discharging stops when $V$ reaches $V_{\max }$ (i.e., $1.2 \mathrm{~V}$ ) for charging or $V_{\min }$ (i.e., $0 \mathrm{~V}$ ) for discharging, respectively. The following equations are used for calculating device performance:
Charge capacity, $Q_{\text {ch }}(\mathrm{mAh})$

$$
Q_{\mathrm{ch}}=I_{\mathrm{ch}} \cdot t_{\mathrm{ch}}
$$

Discharge capacity, $Q_{\text {dis }}(\mathrm{mAh})$

$$
Q_{\mathrm{dis}}=I_{\mathrm{dis}} \cdot t_{\mathrm{dis}}
$$

Coulombic efficiency, $\eta_{\mathrm{C}}$

$$
\eta_{\mathrm{C}}=Q_{\mathrm{dis}} / Q_{\mathrm{ch}}
$$

Charge energy, $E_{\mathrm{ch}}(\mathrm{Wh})$

$$
E_{\mathrm{ch}}=\int_{0}^{t_{\mathrm{ch}}} I_{\mathrm{ch}} \cdot V(t) d t
$$

Discharge energy, $E_{\text {dis }}(\mathrm{Wh})$

$$
E_{\mathrm{dis}}=\int_{0}^{t_{\mathrm{dis}}} I_{\mathrm{dis}} \cdot V(t) d t
$$

Energy efficiency, $\eta_{\mathrm{E}}$

$$
\eta_{E}=E_{\mathrm{dis}} / E_{\mathrm{ch}}
$$

Average power, $P_{\text {dis }}(\mathrm{W})$

$$
P_{\mathrm{dis}}=E_{\mathrm{dis}} / t_{\mathrm{dis}}
$$

Energy reported in the manuscript indicates discharge energy, $E_{\mathrm{dis}}$, which is normalized to the dry mass of both positive and negative electrodes to get specific energy $\left(\mathrm{Wh} / \mathrm{kg}_{\mathrm{dry}}\right)$, or to the combined volume of both electrodes to get energy density $(\mathrm{Wh} / \mathrm{L})$.

The GCD procedure was modified for discharge rate tests and self-discharge tests as follows:

Discharge rate tests were performed by repeatedly charging the cell to $1.2 \mathrm{~V}$ at $0.5 \mathrm{~A} / \mathrm{g}_{\text {dry }}$ and discharging it to $0 \mathrm{~V}$ for 5 cycles each at $0.5 \mathrm{~A} / \mathrm{g}_{\text {dry }}, 1 \mathrm{~A} / \mathrm{g}_{\text {dry }}, 2.5 \mathrm{~A} / \mathrm{g}_{\text {dry }}, 5 \mathrm{~A} / \mathrm{g}_{\text {dry }}, 7.5 \mathrm{~A} / \mathrm{g}_{\text {dry }}$, and $10 \mathrm{~A} / \mathrm{g}_{\text {dry }}$, respectively. The self-discharge rate was studied based on the decay of discharge energy as a function of open circuit time, $\delta$. First, the cell was charged to $1.2 \mathrm{~V}$ by applying a constant current $\left(0.5 \mathrm{~A} / \mathrm{g}_{\mathrm{dry}}\right)$. Then, while 
monitoring the cell potential decay, the cell was left at open circuit for $6 \mathrm{~h}$. After the open circuit period, the cell was discharged to $0 \mathrm{~V}$ by extracting the same constant current density $\left(0.5 \mathrm{~A} / \mathrm{g}_{\text {dry }}\right)$. Energy retention, $\eta_{\mathrm{R}}$, after time $\delta$ at open circuit is defined and calculated by the following formula:

$$
\eta_{\mathrm{R}}(\delta)=E_{\mathrm{dis}}(\delta) / E_{\mathrm{dis}}(0)
$$

\section{Normalized performance metrics and theoretical capacity}

Performance normalization. Electrodes and electrolyte from a $1 \mathrm{M} \mathrm{PVBr} 2 / 3 \mathrm{M} \mathrm{NaBr}$ two-electrode cell massed before and after cycling were $82 \mathrm{mg}$. Based on this mass and the electrolyte density of $1.41 \mathrm{~g} / \mathrm{cm}^{3}$, the electrolyte volume and the relative mass of the different electrolyte components were calculated and summarized in Table S1. The cell performance was then normalized to the total masses of electrodes only (indicated as $\mathrm{g}_{\mathrm{dry}}$ ), and electrodes plus electrolyte (indicated as $\mathrm{g}_{\mathrm{wet}}$ ) in Table $\mathrm{S} 2$.

Table S1. Properties of a $1 \mathrm{M} \mathrm{PVBr}_{2} / 3 \mathrm{M} \mathrm{NaBr}$ electrolyte in a cell with symmetric $10 \mathrm{mg}$ electrodes

\begin{tabular}{|c|l|}
\hline Electrolyte density & $1.41 \mathrm{~g} / \mathrm{cm}^{3}$ \\
\hline Electrolyte mass & $62 \mathrm{mg}$ \\
\hline a. $\mathrm{PVBr}_{2}$ & $20 \mathrm{mg}$ \\
\hline b. $\quad \mathrm{NaBr}$ & $14 \mathrm{mg}$ \\
\hline c. $\mathrm{H}_{2} \mathrm{O}$ & $28 \mathrm{mg}$ \\
\hline Electrolyte volume & $44 \mu \mathrm{L}$ \\
\hline
\end{tabular}

Table S2. Performance metrics normalized to different cell components

\begin{tabular}{|l|l|l|}
\hline & \multicolumn{1}{|c|}{ Dry electrodes } & \multicolumn{1}{|c|}{ Wet electrodes } \\
\hline Mass for normalization (mg) & $20($ Cathode: $10 \mathrm{mg}$; Anode: $10 \mathrm{mg})$ & $\begin{array}{l}82(\text { Electrolyte: } 62 \mathrm{mg} ; \\
\text { electrodes: } 20 \mathrm{mg})\end{array}$ \\
\hline Specific energy $(\mathbf{W h} / \mathbf{k g})$ & $48.5\left(\mathrm{Wh} / \mathrm{kg}_{\text {dry }}\right)$ & $11.8\left(\mathrm{Wh} / \mathrm{kg}_{\text {wet }}\right)$ \\
\hline Specific capacity $(\mathbf{m} \mathbf{A h} / \mathbf{g})$ & $55.6\left(\mathrm{mAh} / \mathrm{g}_{\text {dry }}\right)$ & $13.6\left(\mathrm{mAh} / \mathrm{g}_{\text {wet }}\right)$ \\
\hline Specific power $(\mathbf{W} / \mathbf{k g})$ & $437\left(\mathrm{~W} / \mathrm{kg}_{\text {dry }}\right)$ & $107\left(\mathrm{~W} / \mathrm{kg}_{\mathrm{wet}}\right)$ \\
\hline
\end{tabular}

Theoretical capacity. Based on Scheme 1 in the manuscript, we can write the half-reactions and overall reaction for a cell with pentyl viologen bromide electrolyte:

Cathode half-reaction: $6 \mathrm{Br}_{a q}^{-}+P V_{a q}^{2+} \rightleftharpoons\left[P V^{2+} \cdot 2 B r_{3}^{-}\right]_{s}+4 e^{-}$

Anode half-reaction: $P V_{a q}^{2+}+B r_{a q}^{-}+e^{-} \rightleftharpoons\left[P V^{+\bullet} \cdot B r^{-}\right]_{s}$

Overall cell reaction: $5\left[\mathrm{PVBr}_{2}\right]_{a q} \rightleftharpoons 4\left[\mathrm{PV}^{+\bullet} \cdot \mathrm{Br}^{-}\right]_{s}+\left[\mathrm{PV}^{2+} \cdot 2 \mathrm{Br}_{3}^{-}\right]_{s}$ 
The overall reaction can be balanced without the use of the $\mathrm{NaBr}$ supporting electrolyte. This reaction shows that if all of the pentyl viologen in the electrolyte is utilized, $80 \%$ will be used for faradaic energy storage and $20 \%$ will be used as a complexing agent for $\mathrm{Br}_{3}{ }^{-}$. Based on the calculated mass of $\mathrm{PVBr}_{2}$ in the cell, the theoretical faradaic specific capacity is $47 \mathrm{mAh} / \mathrm{g}_{\text {dry }}$ (after accounting for the $20 \%$ of $\mathrm{PV}^{2+}$ needed for complexing $\mathrm{Br}_{3}{ }_{3}$ ). Combined with an additional $9 \mathrm{mAh} / \mathrm{g}_{\text {dry }}$ of capacitive charging, the total theoretical specific capacity is $56 \mathrm{mAh} / \mathrm{g}_{\text {dry }}$. The measured capacity of $55.6 \mathrm{mAh} / \mathrm{g}_{\text {dry }}$ very closely matches the theoretical value, however the theoretical capacity may be slightly underestimated because additional viologen can be adsorbed to the electrode surface during the electrolyte soaking step of cell fabrication (see the section for "Building the cell stack"). For the theoretical capacity calculated here, this adsorption was not accounted for because its effect should be minor for solutions with high viologen concentrations. ${ }^{2}$

\section{$\underline{\text { Equivalent series resistance and conductivity of solid complexes }}$}

The equivalent series resistance $\left(\mathrm{R}_{\mathrm{ES}}\right)$ is commonly estimated by two different methods: IR drop and electrochemical impedance spectroscopy (EIS). ${ }^{5}$ For the IR drop method, the voltage drop is measured when the current switches between charging and discharging values (without dwelling at the peak potential) and used in the equation $\mathrm{R}_{\mathrm{ES}}=\Delta \mathrm{V} / \Delta \mathrm{I}$ where $\Delta \mathrm{V}$ and $\Delta \mathrm{I}$ are the changes in voltage and current of the IR drop, respectively. For the EIS method, $\mathrm{R}_{\mathrm{ES}}$ is taken as the real part of the complex impedance found by extrapolating the low-frequency region of a Nyquist plot to $\operatorname{Im}(Z)=0$. Both of these measurements were performed on a $1 \mathrm{M} \mathrm{PVBr}_{2} / 3 \mathrm{M} \mathrm{NaBr}$ cell in the fully charged state $(100 \%$ state of charge (SOC), $1.2 \mathrm{~V})$ and in the fully discharged state $(0 \% \mathrm{SOC}, 0 \mathrm{~V})$. The data are shown in Figure S6 and the calculated $R_{E S}$ values are summarized in Table $S 3$. When the cell is fully charged, the $R_{E S}$ calculated by both methods is ca. 2 times higher than in the fully discharged state. This suggests that the precipitated solid complexes formed during charging have low electrical conductivity, as they increase the total resistance of the cell by ca. $190 \%$ (IR drop method) to $225 \%$ (EIS method).

Table S3. Equivalent series resistance $\left(\mathrm{R}_{\mathrm{ES}}\right)$ of a $1 \mathrm{M} \mathrm{PVBr}_{2} / 3 \mathrm{M} \mathrm{NaBr}$ cell

\begin{tabular}{|l|ll|ll|}
\hline & \multicolumn{2}{|l|}{ IR drop method } & \multicolumn{2}{l|}{ EIS method } \\
\hline Discharged (0\% SOC) & $1.85 \Omega$ & $\left(1.45 \Omega \cdot \mathrm{cm}^{2}\right)$ & $2.32 \Omega \quad\left(1.82 \Omega \cdot \mathrm{cm}^{2}\right)$ \\
\hline Charged (100\% SOC) & $3.50 \Omega$ & $\left(2.75 \Omega \cdot \mathrm{cm}^{2}\right)$ & $5.18 \Omega \quad\left(4.07 \Omega \cdot \mathrm{cm}^{2}\right)$ \\
\hline
\end{tabular}




\section{Additional analytical measurements}

Cyclic voltammetry of viologens. The cyclic voltammetry experiments were carried out in a conventional three electrode cell using a Potentiostat $600 \mathrm{C}(\mathrm{CH}$ Instruments, Austin, TX). A glassy carbon disc $(\mathrm{CH}$ Instruments, $3 \mathrm{~mm}$ diameter) served as the working electrode and a platinum wire as the counter electrode. The glassy carbon disc electrode was polished using polishing alumina $(0.05 \mu \mathrm{m})$ and the Pt disc electrode was rinsed first with acetonitrile followed by water and methanol, and then dried before each experiment. A saturated calomel reference electrode (SCE, $\mathrm{CH}$ Instruments) was used. The supporting electrolyte was $0.5 \mathrm{M} \mathrm{KBr}$ dissolved in ultrapure water obtained from a Milli-Q Simplicity ${ }^{\mathrm{TM}} 185$ system with resistivity $\geq$ $18.2 \mathrm{M} \Omega \cdot \mathrm{cm}$.

UV-Vis measurements for testing complexation of viologens and $\mathrm{Br}_{3}{ }^{-}$. The UV-Vis spectra were acquired on an Agilent $8453 \mathrm{UV}$-Vis spectrophotometer equipped with a cuvette holder. All spectra were recorded under ambient conditions with a $1 \mathrm{~cm}$ light-path.

To generate spectra of uncomplexed viologen dications, $0.5 \mathrm{~mL}$ of each $60 \mathrm{mM}$ viologen solution was combined with $1 \mathrm{~mL}$ water in $1.5 \mathrm{~mL}$ centrifuge tubes. Tubes were agitated with a vortex mixer for $1 \mathrm{~min}$ and left to sit overnight. Before UV-Vis measurements, tubes were centrifuged for $5 \mathrm{~min}$ at 4,000 rpm and then a $5 \mathrm{uL}$ sample of the solution was diluted 400 times into $1.995 \mathrm{~mL}$ water in a quartz cuvette. The capped cuvette was shaken to ensure a homogeneous analyte.

To generate spectra of the viologens after complexation with $\mathrm{Br}_{3}{ }^{-}$, each $0.5 \mathrm{~mL}$ of $60 \mathrm{mM}$ viologen solution was combined with $0.5 \mathrm{~mL}$ water and $0.5 \mathrm{~mL}$ of $120 \mathrm{mM} \mathrm{Br}_{3}{ }^{-}$solution. Prepared samples were processed with the same methods stated above before UV-Vis measurements.

Optical absorption data for both complexed and uncomplexed viologen samples were normalized to the absorbance at the absorption maxima for the uncomplexed sample (Figure S5). 


\section{$\underline{\text { Supplementary Figures }}$}

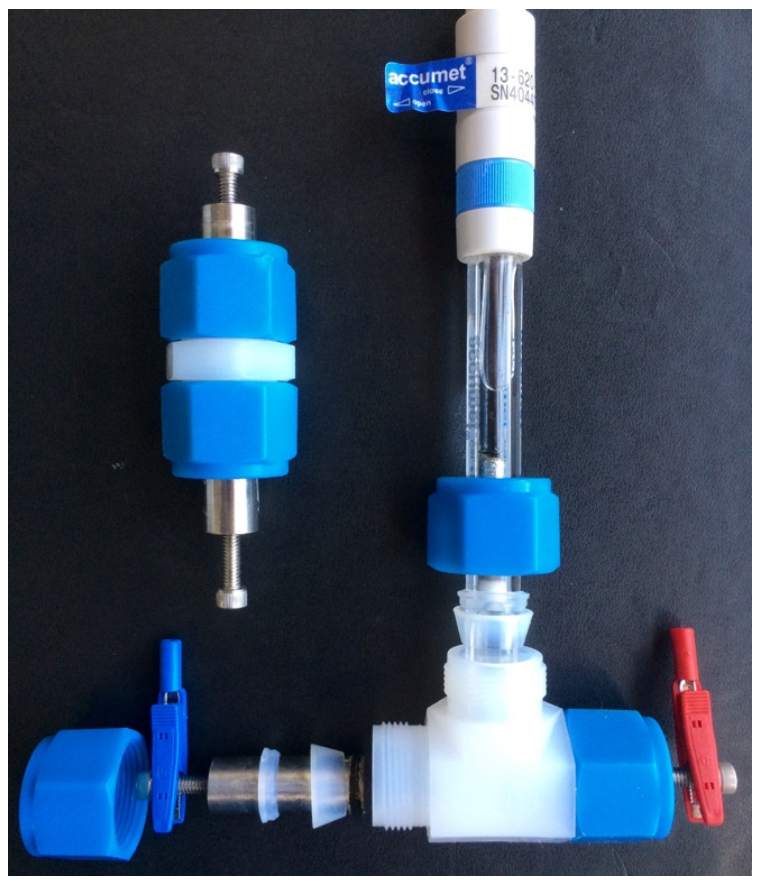

Figure S1. Custom Swagelok Cells. Two PFA Swagelok cells are shown: a fully assembled two-electrode cell (left) and a partially assembled three-electrode cell (bottom/right).

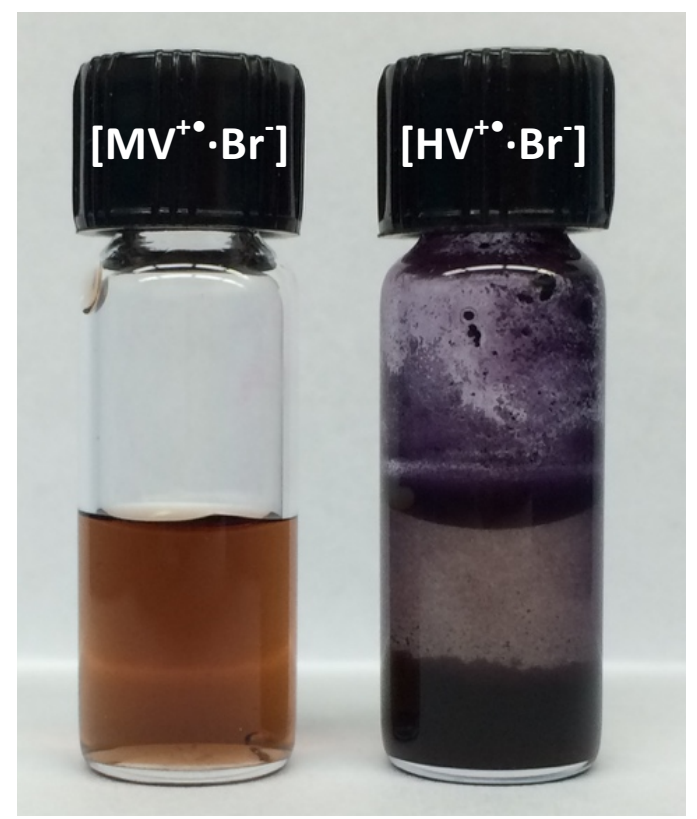

Figure S2. Complexation of viologen radicals $\left(\mathrm{V}^{+\bullet}\right)$ by the bromide anion $\left(\mathrm{Br}^{-}\right)$to generate a $\left[\mathrm{V}^{+\bullet} \cdot \mathrm{Br}^{-}\right]$ complex. (left) soluble $\left[\mathbf{M V}^{+\bullet} \cdot \mathbf{B r}^{-}\right]$and (right) insoluble $\left[\mathbf{H V}^{+\bullet} \cdot \mathbf{B r}^{-}\right]$formed by reducing a solution of 60 $\mathrm{mM} \mathrm{V}^{2+}$ in the presence of $0.1 \mathrm{M} \mathrm{KBr}$ with excess sodium dithionite $\left(\mathrm{Na}_{2} \mathrm{~S}_{2} \mathrm{O}_{4}\right)$. 


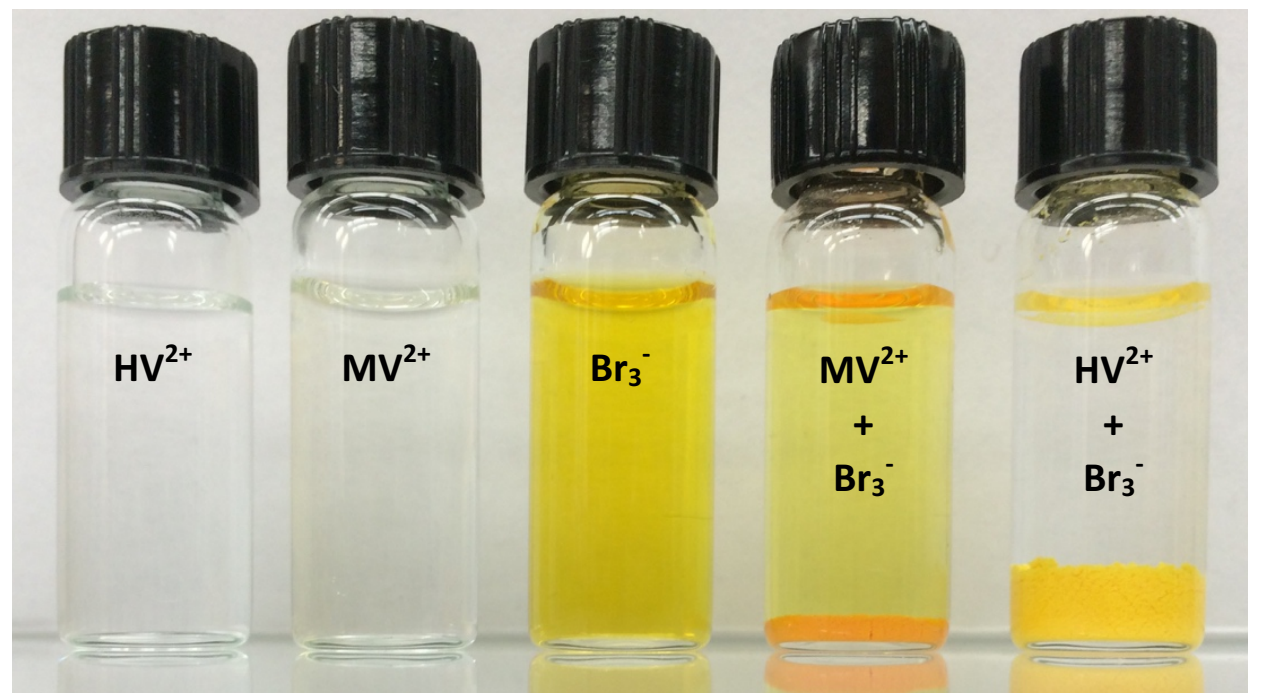

Figure S3. Complexation of $\mathrm{Br}_{3}^{-}$by methyl and heptyl viologen dications to generate $\left[\mathrm{V}^{2+} \cdot 2 \mathrm{Br}_{3}{ }^{-}\right]$. $20 \mathrm{mM} \mathrm{MVCl}_{2}$ or $\mathrm{HVBr}_{2}$ (left) and $40 \mathrm{mM} \mathrm{Br}_{3}^{-}$(center) form solid complexes of $\left[\mathrm{MV}^{2+} \cdot 2 \mathrm{Br}_{3}^{-}\right]$or $\left[\mathrm{HV}^{2+} \cdot 2 \mathrm{Br}_{3}{ }^{-}\right]$(right) when mixed in aqueous solution. The degree of complex precipitation is higher for $\mathrm{HV}$ than for MV. In the case of MV, a significant amount of $\mathrm{Br}_{3}{ }^{-}$remains dissolved in solution, which can be visually observed as a yellow tint compared to the clear $\mathrm{HV} / \mathrm{Br}_{3}^{-}$solution.

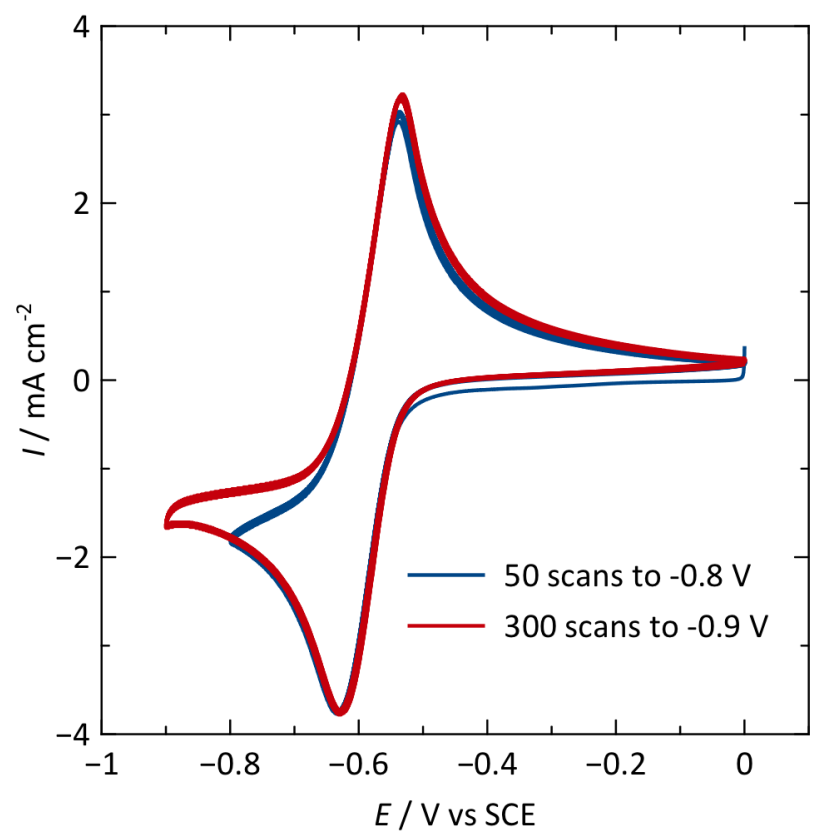

Figure S4. Extended cyclic voltammetry of $\mathrm{MV} / \mathrm{Br}$ electrolyte. Repeated cyclic voltammograms of 50 $\mathrm{mM} \mathrm{MVCl}_{2} / 0.2 \mathrm{M} \mathrm{KBr}$ electrolyte are shown for 50 scans to $-0.8 \mathrm{~V}$ followed by 300 scans to $-0.9 \mathrm{~V}$ at a scan rate of $10 \mathrm{mV} / \mathrm{s}$. 


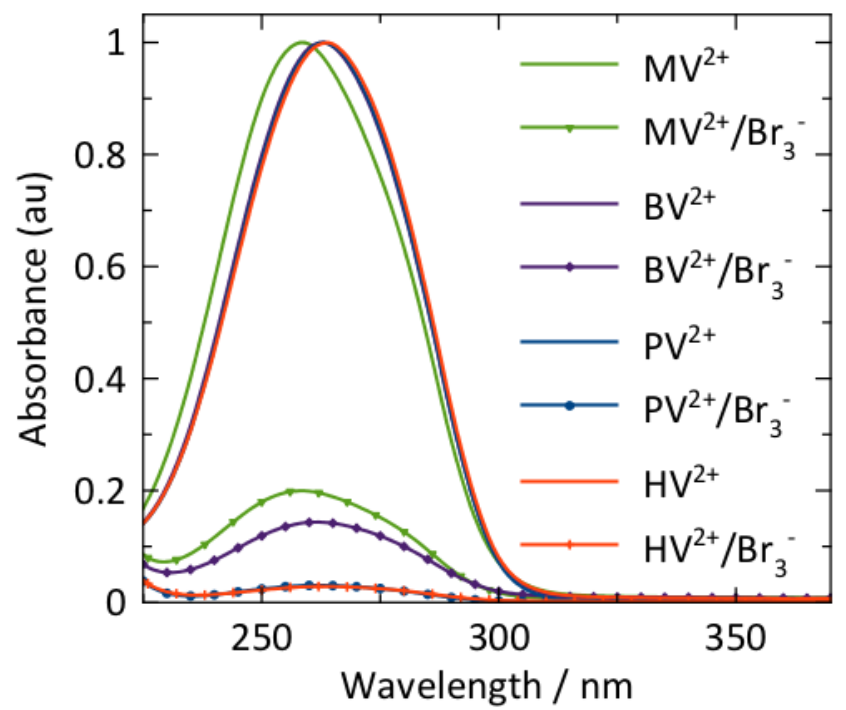

Figure S5. UV-Vis absorption from viologen/tribromide $\left(\mathrm{Br}_{3}{ }^{-}\right)$complexation studies. The spectra shown are for $20 \mathrm{mM}$ viologen solutions with and without an additional $40 \mathrm{mM} \mathrm{Br}_{3}{ }^{-}$, which precipitates with the viologen and decreases the concentration of $\mathrm{V}^{2+}$ dissolved in the solution. Spectra for both complexed and uncomplexed viologen samples were normalized to the absorption maxima for the uncomplexed sample. Pentyl viologen (PV) forms a solid complex as effectively as heptyl viologen (HV). Butyl viologen (BV) shows similar complexing capacity to methyl viologen (MV).
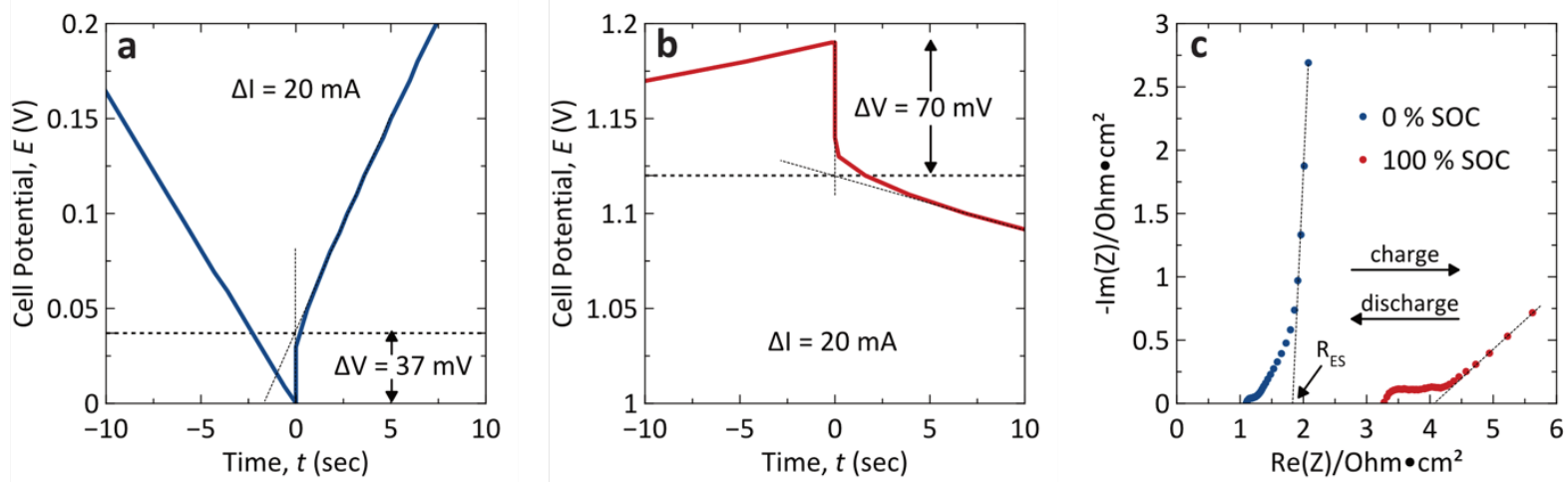

Figure S6. Measuring equivalent series resistance $\left(\mathbf{R}_{\mathbf{E S}}\right)$. IR drop for a $1 \mathrm{M} \mathrm{PVBr} / 3 \mathrm{M} \mathrm{NaBr}$ cell immediately after (a) discharging and (b) charging at $\pm 10 \mathrm{~mA}$, as well as (c) Nyquist impedance spectra from $0.2 \mathrm{MHz}$ to $0.1 \mathrm{~Hz}$ for the fully discharged (0\% SOC) and fully charged (100\% SOC) conditions. The increase in $\mathrm{R}_{\mathrm{ES}}$ in the charged state is evidenced by the larger IR drop, contact resistance, and charge transfer resistance. This behaviour is related to the formation of precipitated solid complexes with low electrical conductivity at both electrodes, and consistent with the operating mechanism of the cell. 


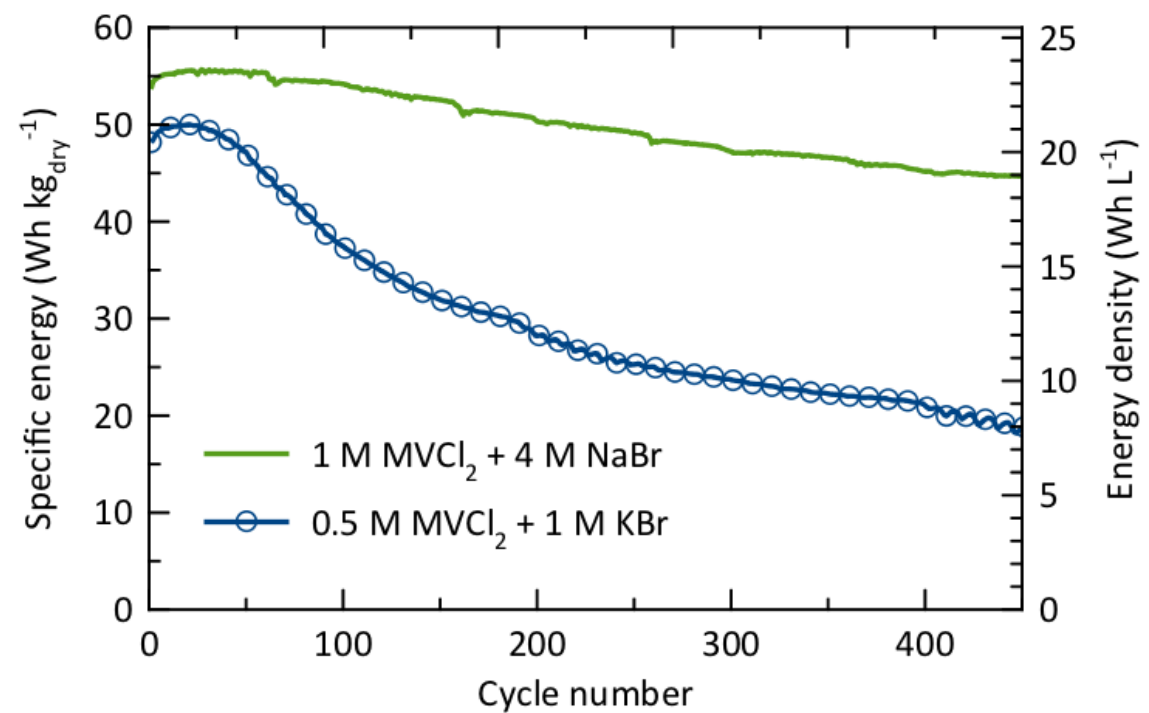

Figure S7. Cycling stability for concentrated $\mathbf{M V} / \mathbf{B r}$ cell. A $1 \mathrm{M} \mathrm{MVCl}_{2} / 4 \mathrm{M} \mathrm{NaBr}$ cell and a $0.5 \mathrm{M}$ $\mathrm{MVCl}_{2} / 1 \mathrm{M} \mathrm{KBr}$ cell are cycled at $0.5 \mathrm{~A} / \mathrm{g}_{\text {dry }}$ to $1.3 \mathrm{~V}$ and $1.4 \mathrm{~V}$, respectively. The highly concentrated cell exhibits significantly less capacity fade over 450 charge/discharge cycles.

\section{References}

(1) Maciá-Agulló, J. A.; Moore, B. C.; Cazorla-Amorós, D.; Linares-Solano, A. Carbon 2004, 42, 1367.

(2) Chun, S.-E.; Evanko, B.; Wang, X.; Vonlanthen, D.; Ji, X.; Stucky, G. D.; Boettcher, S. W. Nat. Commun. 2015, 6, 7818.

(3) Lin, R.-L.; Li, J.-Q.; Liu, J.-X.; Kaifer, A. E. J. Org. Chem. 2015, 80, 10505.

(4) Wang, T.; Kelley, M.; Cooper, J. Inorg. Chem. 1994, 33, 5872.

(5) Zhang, S.; Pan, N. Adv. Energy Mater. 2015, 5, 1401401. 